Гріненко О. І., к. військ.н., доцент;

Кутовий О. П., к.т.н., с.н.с.;

Шапталенко М. І., к.т.н., доцент

Центр воєнно-стратегічних досліджень Національного університету оборони України імені Івана Черняховського, Київ

\title{
Мобілізаційні спроможності оборонного сектору національної економіки: принципи розвитку та підтримки
}

Резюме. У статті обгрунтовані та аналізуються принципи розвитку та підтримки мобілізаційних спроможностей оборонного сектору національної економіки з виробництва боєприпасів для впровадження принципово нової єдиної воєнно-економічної, військово-промислової та військово-технічної політики. Встановлено їх зв'язок із принципами оборонного планування на основі спроможностей.

Ключові слова: принципи; боєприпаси; мобілізаційна підготовка та мобілізація; мобілізаційні спроможності; оборонний сектор національної економіки; оборонне планування.

Постановка проблеми. Незважаючи на відсутність протягом понад 25 -ти років вкрай необхідного ефективного оборонного сектору національної економіки до цього часу не визначені принципи його розвитку i підтримки. Це питання найактуальніше у світі переходу Збройних Сил України на оборонне планування на основі спроможностей.

Ступінь розробленості проблеми. У публікаціях $[1,2]$ наведений досвід провідних країн світу в організації виробництва озброєння, військової техніки, інших матеріально-технічних засобів і послуг через використання мобілізаційних спроможностей оборонного сектору національної економіки. У вітчизняних публікаціях за цім напрямом недостатньо інформації щодо понятійного апарату формування мобілізаційних спроможностей оборонного сектору національної економіки в умовах ринкових економічних стосунків.

Метою дослідження $€$ визначення обгрунтованих принципів розвитку та підтримки мобілізаційних спроможностей оборонного сектору національної економіки.

Викладення основного матеріалу. Міністерство оборони України планово проводить заходи до переходу на оборонне планування на основі спроможностей. До того ж були визначені принципи оборонного планування на основі спроможностей, а саме [1]:

реалістичність, яка полягає в збалансованості вартості заходів із досягнення спроможностей та виділеними коштами; результативність, яка полягає у досягненні визначених цілей через виконання завдань і заходів у плановий період;

ефективність, яка полягає в оптимальному співвідношенні витрачених ресурсів і досягнутого результату;

централізація управління плануванням для забезпечення збалансованого розвитку складових сил оборони;

безперервність управління плануванням і моніторингом спроможностей;

системність і паралельність процесів планування та моніторингу для забезпечення оперативності процесу управління розвитком спроможностей;

об'єктивність і колегіальність під час підготовки пропозицій для прийняття рішень у процесі планування;

цілісність, яка забезпечується взаємоузгодженням документів планування розвитку складових сил оборони на довго-, середньо- та короткостроковий період 3 урахуванням їх функціонального призначення; планування створення нових i модернізація наявних видів озброєння, військової техніки, виробничих потужностей для їх розроблення, виготовлення та освоєння і впровадження нових технологій;

узгодженість оборонного планування із стратегічним плануванням застосування Збройних Сил України, заходами мобілізаційної підготовки національної економіки, системи життєзабезпечення населення і підготовки території держави до оборони.

Отже, заходи мобілізаційної підготовки національної економіки, які плануються на основі iї спроможностей, мають бути 
узгоджені зі стратегічним i оборонним плануванням застосування Збройних Сил України.

У Радянському Союзі до мобілізаційної підготовки економіки був характерний адміністративно-командний підхід, який зводився до досягнення мети будь-якою ціною. До того ж державі необхідно було задіяти всі ресурси, які спрямовувались на одну, або декілька цілей у збиток іншим галузям, що порушувало гармонійний розвиток економіки держави. Такий підхід був характерний у $\mathrm{XX}$ столітті, коли відбувались “тотальні війни”, а економіка держави отримала назву "мобілізаційна економіка".

Мобілізаційна економіка була характерною для СРСР і спроби їі дотримання панували певний час i після отримання Україною незалежності.

Мобілізаційна економіка базувалась на таких характерних принципах:

принции досягнення мети будь-якою ціною і переважне використання через це неекономічних методів впливу на оборонні підприємства та встановлення їм мобілізаційних завдань;

принции головної ланки припускає концентрацію ресурсів у тій ланці економічної системи (як правило, в ОПК), від якої залежить успіх протидії навислій над державою загрозі, зокрема внаслідок вилучення ресурсів 3 інших ланок економіки (зазвичай, що виробляють продукцію народного споживання), менш важливих 3 погляду керівництва для досягнення поставленої мети;

принциип командності - усі суб'єкти економіки є єдиною командою, яка спільно розв'язує загальну задачу у пріоритетній ланці економічної системи та здійснюе стратегічне, оборонне і мобілізаційне планування розвитку оборонних галузей економіки;

принции свідомості - необхідність мобілізаційних приготувань економіки i пов'язані 3 ними витрати заради протидії навислій над державою загрозою має усвідомлюватися залученими суб'єктами економіки.

Перехід економіки України на ринкові відносини призвів до того, що принципи мобілізаційної економіки не працюють, оскільки спираються на командноадміністативні підходи. Це потребувало визначення нових принципів до розвитку та підтримки мобілізаційних спроможностей національної економіки, які знайшли своє відображення в Законі України "Про мобілізаційну підготовку та мобілізацію" [2].

Запропоновано під мобілізаційними спроможностями оборонного сектору національної економіки розуміти властивості специфічної частини економіки держави, які забезпечують розгортання військового виробництва у визначених потребах, зміну економічних пропорцій в інтересах всебічного збільшення виробництва військової продукції, перебудову роботи певної кількості органів управління державою та виробництвом, переведення роботи інформаційного простору, трудових ресурсів, промисловості, транспорту, зв'язку, енергетики, будівництва, сільського господарства, системи медичного, ветеринарного, санітарно-епідемічного забезпечення, видобутку природних ресурсів, формування системи життєзабезпечення населення в інтересах задоволення потреб воєнного часу, забезпечення живучості та стійкості господарчого механізму держави, зміни діяльності наукових i дослідноконструкторських закладів для задоволення потреб оборони.

Тоді розвиток i підтримка мобілізаційних спроможностей оборонного сектору національної економіки - це процеси, які спрямовані на набуття та утримання структурною одиницею (підприємством, установою) оборонного сектору економіки або ïх сукупністю (галуззю) спроможності виконувати певні завдання (мобілізаційні замовлення) за певних умов обстановки, ресурсного забезпечення та відповідно до встановлених стандартів.

У Законі України "Про мобілізаційну підготовку та мобілізацію" [2] визначаеться, що мобілізаційна підготовка (розвиток $\mathrm{i}$ підтримка мобілізаційних спроможностей) здійснюється на основі таких принципів:

централізоване керівництво;

завчасність;

плановість;

комплексність і погодженість;

персональна відповідальність за виконання заходів щодо мобілізаційної підготовки та мобілізації;

додержання прав підприємств, установ, організацій та громадян;

гарантована достатність;

наукова обгрунтованість;

фінансова забезпеченість.

Перехід до оборонного планування орієнтованого на спроможності, що на сьогодні відбувається у Збройних Силах 
України, потребує переходу i до нової політики - мобілізаційного планування на основі спроможностей оборонної промисловості.

Нова Воєнна доктрина України [3] передбачає впровадження принциипово нової єдиної воєнно-економічної, військовопромислової та військово-технічної політики. Зрозуміло, що під час впровадження такої нової політики потребують ретельного перегляду і мобілізаційні питання.

Головною рисою такої політики слід вважати перехід до оборонного та мобілізаційного планування, орієнтованого на спроможності у трьох сферах: державному плануванні розвитку Збройних Сил України, державному плануванні розвитку озброєння та військової техніки i державному плануванні розвитку ОСНЕ.

У новій редакції Воєнної Доктрини України визначений напрям оборонномобілізаційної достатності, який передбачає удосконалення системи створення та збереження мобілізаційних запасів на державному, регіональному та місцевому рівнях, розвитку й утриманні виробничих потужностей звичайного i мобілізаційного призначення, формування та підтримання в належному стані державного матеріального резерву.

Принципи виконання цих завдань визначені у проекті нового Закону України "Про мобілізаційну підготовку та мобілізацію”. Їх склад майже не змінився, додатково наведений принцип скритності.

Сутність принципів наведених у проекті закону нового Закону України "Про мобілізаційну підготовку та мобілізацію” зводиться до такого:

1. Централізоване

керівництво передбачає створення і розвиток ефективної системи централізованого управління i планування мобілізаційною підготовкою. В умовах ринкових відносин цей принцип передбачає перехід від адміністративнокомандного управління до змішаного управління або децентралізованого управління.

2. Завчасність передбачає проведення всіх заходів мобілізаційного планування оборонної промисловості та їх коригування в мирний час.

3. Плановість передбачає планове вирішення всіх питань удосконалення системи створення та збереження мобілізаційних запасів на державному, регіональному та місцевому рівнях, розвитку й утримання виробничих потужностей звичайного та мобілізаційного призначення, формування та підтримання в належному стані державного матеріального резерву, 3 використанням програмно-цільового методу планування.

4. Комплексність $\quad$ i погодженість передбачає комплексне вирішення всіх питань мобілізаційної підготовки та їх погодженість між замовником мобілізаційцної продукції та іï виконавцями.

\section{5. Скритність}

передбачає нерозголошення питань мобілізаційного планування та їх виконання всіма суб'єктами мобілізаційного планування i виконання мобілізаційних завдань.

6. Персональна відповідальність за виконання заходів щодо мобілізаційної підготовки і мобілізації передбачає сувору відповідальність всіх суб'єктів мобілізаційного планування i виконання мобілізаційних завдань за своєчасне проведення планування i виконання планів мобілізації в особливий період.

\section{7. Додержання прав підприємств,} установ, організащуій та громадян передбачає законодавче врегулювання всіх питань мобілізаційного планування та мобілізації. В умовах ринкових відносин реалізація цього принципу $\epsilon$ новою задачею, яка передбачає застосування нових підходів у взаємовідносинах приватних оборонних підприємств i державних замовників оборонної продукції.

8. Гарантована достатність передбачає під час проведення мобілізаційного планування дотримання певного рівня ефективності заходів мобілізаційної підготовки і мобілізації, за якого забезпечується гарантоване забезпечення Збройних Сил матеріальними ресурсами в особливий період.

9. Наукова обтрунтованість передбачає наявність науково-методичного апарату, за допомогою якого обгрунтовуються всі заходи мобілізаційного планування, визначаються потреби у матеріальних ресурсах i спроможності оборонного сектору економіки.
10. Фінансова
забезпеченість

передбачає наявність достатньої кількості фінансових ресурсів для реалізаціїі всіх заходів мобілізаційного планування національної економіки та його реалізації.

Висновки. У новій редакції Воєнної Доктрини України визначені вимоги до напряму оборонно-мобілізаційної достатності нової єдиної воєнно-економічної, військово- 
промислової та військово-технічної політики напряму, який передбачає:

удосконалення системи створення та збереження мобілізаційних запасів на державному, регіональному i місцевому рівнях;

розвиток й утримання виробничих потужностей звичайного i мобілізаційного призначення;

формування та підтримання в належному стані державного матеріального резерву.

Напрям оборонно-мобілізаційної достатності реалізується такими принципами: централізоване керівництво; завчасність; плановість; комплексність і погодженість; скритність; персональна відповідальність за виконання заходів щодо мобілізаційної підготовки та мобілізації; додержання прав підприємств, установ, організацій і громадян; гарантована достатність; наукова обгрунтованість; фінансова забезпеченість.

Подальші дослідження доцільно спрямувати на аналіз і розв'язання проблем функціонування системи мобілізаційного планування в інтересах задоволення потреб Збройних Сил України.

СПИСОК ВИКОРИСТАНОЇ ЛІТЕРАТУРИ

1. Гріненко О. І. “Шляхи оснащення Збройних Сил України озброєнням, військовою технікою та матеріально-технічними засобами в особливий період” / Кутовий О. П. Збірник наукових праць ЦВСД НУОУ імені Івана Черняховського. № 1(53). - НУОУ, 2015. - c. 81-87.

2. Гріненко О. I. "Мобілізаційна підготовка національної економіки в контексті сучасних воєнних конфліктів" / Денежкін М. М. Кутовий О. П. // Наука і оборона. - 2013. - № 3. С. 8-14.

3. Петренко А. Г. "Рекомендації 3 оборонного планування на основі спроможностей в Міністерстві оборони України та Збройних Силах України”. - МО України. - 2017. - 12 с.

4. Закон України "Про мобілізаційну підготовку та мобілізацію" // Відомості Верховної Ради України. - 1993. - № 44, розд. 1, ст. 3.

5. Воєнна доктрина України (Затверджено Указом Президента України від 24 вересня 2015 року № $555 / 2015)$.

6. Закон України "Про державне оборонне замовлення"// Відомості Верховної Ради України. - 1999. - № 17, розд. 1, ст. 3.

Стаття надійшла до редакційної колегії 21.01.2019

Гриненко А. И., к.воен.н., доцент;

Кутовой О. П., К.т.н., с.н.с.;

Шапталенко Н. И., к.т.н., доцент

Центр военно-стратегических исследований Национального университета обороны Украины имени Ивана Черняховского, Киев

\section{Мобилизационные возможности оборонного сектора национальной экономики: принципы развития и поддержки}

Резюме. В статье обоснованы и анализируются принципы развития и поддержки мобилизационных возможностей оборонного сектора национальной экономики по производству боеприпасов с целью внедрения принципиально новой единой военно-экономической, военно-промышленной и военнотехнической политики. Установлена их связь с принципами оборонного планирования на основе возможностей.

Ключевые слова: принципы; боеприпасы; мобилизационная подготовка и мобилизация; мобилизационные способности; оборонный сектор национальной экономики; оборонное планирование.

\section{A. Grinenko, PhD (Military), assistant professor; \\ O. Kutoviy, PhD (Technical), senior researcher;}

N. Shaptalenko, PhD (Technical), assistant professor

Center for Military and Strategic Studies of the National Defence University of Ukraine named after Ivan Cherniakhovskyi, Kyiv

Mobilization capabilities of the national economy's defense sector: development and support principles

Resume. The article substantiates and analyzes the principles of development and support of the mobilization capabilities of the national defense sector for the production of ammunition with a view to introducing a fundamentally new unified military-economic, military-industrial and military-technical policy. Their link with the principles of defense planning based on capabilities is established.

Keywords: principles; ammunition; mobilization preparation and mobilization; mobilization capabilities; defense sector of the national economy; defense planning. 